MACIEJ WITKOWSKI

(DD https://orcid.org/0000-0001-7072-8513

Akademia WSB

Dąbrowa Górnicza

\title{
Mniejszość romska w Polsce: czego brakuje w koncepcji integracji?'
}

The Romani minority in Poland: what is lacking in the integration concept?

\begin{abstract}
The author presents the results of own research carried out within the Romani community in two villages of the Podhale region (respectively in 2011-2017 and 2013-2016). The author focuses particularly on the reasons for differences in multiple aspects of functioning of the two groups studied. The results of own research presented and analysed in the paper are based on observations and free-form interviews with both Romani and non-Romani people.
\end{abstract}

Key words: Romani minority, integration, Podhale, Poland, intercultural communication, etnology

\section{Wprowadzenie}

Sytuacja społeczna Romów w Polsce jest na tle innych społeczeństw europejskich, a zwłaszcza środkowoeuropejskich, dość specyficzna (zob. Liegeois 2007, 31; por. Talewicz-Kwiatkowska 2013; Szewczyk 2013). Przede wszystkim ich liczba w stosunku do populacji większościowej jest stosunkowo niewielka. Najprawdopodobniej mamy około 20-25 tys. Romów w 38-milionowym państwie (Program integracii spotecżności romskiej w Polsce na lata 2014-2020, 2014, 12). Skala zjawisk określanych w kategoriach „problemu społecznego" związanych z trybem życia Romów jest stosunkowo

\footnotetext{
1 Projekt został sfinansowany ze środków Narodowego Centrum Nauki przyznanych na podstawie decyzji numer DEC-2018/29/B/HS5/00019.
} 
mała. Sytuacje te mają charakter przede wszystkim lokalny. Większość konfliktów społecznych, w których stronami są Romowie i nie-Romowie, ogniskuje się w obszarach bezpośredniego sąsiedztwa. W konsekwencji sytuacja Romów i relacje z nimi nie są elementem debaty politycznej (Witkowski 2016; Wódz, Witkowski 2013). Popularny temat „romskiego zagrożenia demograficznego" (Stewart 2013; Nowicka 2003; Połeć 2003; Witkowski 2003), w innych krajach Europy Wschodniej i na Bałkanach zazwyczaj elektryzujący opinię publiczną, w Polsce się nie pojawia. Podobnie niemal nikt nie podnosi sprawy romskiej samorządności lokalnej czy przedstawicielstwa politycznego Romów na arenie ogólnopolskiej w ramach instytucji powszechnego systemu politycznego. Romowie korzystaja natomiast ze specjalnych, gwarantowanych mniejszościom przez państwo polskie i prawo międzynarodowe (Sobotka 2010; Janusz 2011) instytucji partycypacyjnych, których znaczenie jest jednak niewielkie. Prawdopodobnie, bo w gruncie rzeczy nie mamy w tej sprawie wiarygodnych aktualnych danych (Nowicka 2003, 31-33), zdecydowana większość Romów w Polsce należy do grupy określanej jako Polska Roma, mającej stosunkowo konserwatywny stosunek do własnej tradycji i dość hermetycznej.

Wobec opisanego stanu rzeczy ani polscy politycy, ani urzędnicy uczestniczący w międzynarodowych gremiach kreujących politykę Unii Europejskiej wobec społeczności romskiej nie wykazują jakiejś szczególnej inicjatywy. W Polsce nigdy nie pojawiła się idea, by ze strategii rozwiązywania problemów społeczności romskich uczynić kwestię międzynarodowa, o co aktywnie zabiegała i zabiega większość państw Europy Środkowo-Wschodniej (Vermeersch 2006; Klimova-Alexander 2005; Barany 2002). Rząd polski stał się biernym wykonawcą wspólnej polityki europejskiej wobec społeczności romskich, a w każdym razie jej głównych wytycznych. Na poziomie konkretnych rozwiązań wprowadzających w życie wspólne europejskie ramy ideowe polityki romskiej, dzięki istnieniu tzw. mechanizmów elastyczności europejskiej negocjowanej demokracji (Wódz, Wódz 2007), w ciagu ostatnich 15-20 lat ukształtował się stabilny zestaw instrumentów oddziaływania i pragmatycznej logiki ich wykorzystywania. Udział romskich liderów z Polski w kreowaniu wspólnej polityki, choć prestiżowy, jak w przypadku Stanisława Stankiewicza - wieloletniego prezydenta International Romani Union - nie może być traktowany jako istotne zaakcentowanie specyficznej sytuacji Romów w Polsce. Praktyki integrowania Romów wytworzyły w wielu miejscach w Polsce szereg wyjątkowych lokalnych relacji społecznych, a ich konsekwencji nie można uogólniać na inne państwa objęte wspólną europejską polityką. 
Jednak gdy na europejską politykę równości i dążenie do stworzenia społeczeństwa inkluzyjnego spogląda się z perspektywy polityki wobec społeczności romskich w Polsce, można wyraźnie dostrzec jej ograniczenia. Główny problem zasadza się w założeniu, że współczesne koncepcje polityki integrowania Romów w UE i w Polsce zostały zbudowane dzięki przekonaniu, że „ekspercka wiedza” o relacjach społeczeństwa większościowego z Romami jest wystarczająca i godna zaufania. Zjawisko to implikuje głębokie poczucie moralnej słuszności, z jaką twórcy i realizatorzy polityki integrowania Romów narzucają konkretne sposoby działania lokalnym społecznościom. W swoim artykule zamierzam przyjrzeć się dwóm bardzo różnym kontekstom podejmowania prób integrowania wspólnot romskich ze społecznościami lokalnymi i na tej podstawie wskazać pewne zasadnicze ograniczenie instytucjonalnych praktyk integrowania Romów.

\section{Dwie wioski}

Zamierzam porównać sytuację w dwóch podhalańskich wioskach, w których znajduja się romskie osady. W obu przeprowadziłem badania etnograficzne, na które składają się dokonywane w ciagu sześciu lat obserwacje i swobodne wywiady z Romami i nie-Romami. Wybór nie jest przypadkowy. W jednej z wiosek wzory tzw. integracji społecznej Romów wyznaczają realizatorzy grantów. W drugiej większość Romów wstąiła do Kościoła Zielonoświątkowego, dokonując interesującego „otwarcia” swojej tożsamości. Przyglądając się zmianom zachodzącym w społecznościach romskich konwertytów i zestawiając je ze zjawiskami w społeczności Romów integrowanych przez projekty marketingu społecznego, otrzymujemy interesujący materiał porównawczy. W sytuacji, gdy dwie dość zbliżone do siebie społeczności Bergitka Roma², żyjące w podobnym społecznym otoczeniu i na podobnym poziomie materialnym, których członkowie są w dodatku często blisko spokrewnieni, podlegaja zupełnie innym przeobrażeniom, pojawia się

\footnotetext{
2 Romowie są przez społeczności zewnętrzne często postrzegani jako grupa jednorodna. W rzeczywistości wewnątrz romskiego świata - także w Polsce - występuja głębokie podziały. W Polsce dwie główne grupy Romów to Polska Roma (czasem nazywani Cyganami Nizinnymi) i Bergitka Roma (nazywani też Cyganami Wyżynnymi). Bergitka Roma są przez Polską Romę uważani za grupę niższą, która nie stosuje się we właściwy sposób do romskich zasad postępowania.
} 
potrzeba interpretacji różnic. Dane etnograficzne, które udało się uzyskać, pozwalają na ostrożne porównanie sytuacji w obu osadach. Nie ma oczywiście mowy o wyjaśnieniach w kanonie ,jedynej różnicy”. Każde proste odniesienie doświadczeń z jednej osady do sytuacji zastanej w drugiej budzi szereg zastrzeżeń. Jest to zarówno konsekwencja interpretacji kulturowej opartej na gęstym opisie niepowtarzalnego kontekstu, jak i natury etnografii: opisu uczestnictwa badacza w życiu badanych społeczności.

Obie osady są pod wieloma względami podobne. Przede wszystkim mamy tu do czynienia z kilkudziesięcioosobowymi społecznościami romskimi wyraźnie odrębnymi od reszty mieszkańców podhalańskiej wioski. $\mathrm{Na}$ odrębność składają się różnice w sposobie życia, zamieszkiwanej przestrzeni, sposobach komunikowania się, wyglądzie. Odrębność wyraża się także jasnym mentalnym rozgraniczeniem na Romów i Górali w strukturze świata społecznego wszystkich mieszkańców wioski. Romowie z obu osad sa mieszkańcami swoich wsi od wielu pokoleń. Właściwie nikt z mieszkańców nie jest w stanie wyjaśnić genezy ich pojawienia się, ani określić, kiedy do tego doszło. Status materialny i społeczny Romów jest w obu przypadkach wyraźnie niższy od Górali, co w obu lokalizacjach Romowie i nie-Romowie interpretuja nieco inaczej. Wspólnym elementem kontekstu jest także to, że w obu miejscach wyraźnie widać odbywające się tam praktyki integrowania Romów: projekty realizowane w paradygmacie marketingu społecznego mające na celu wywołanie ,pozytywnej zmiany” w dotychczasowym życiu Romów. Wspólnym normatywnym modelem działań są ramy realizowanej w Unii Europejskiej „strategii integracji Romów” wprowadzanej w życie dzięki znacznym środkom finansowym i szczególnym zinstytucjonalizowanym mechanizmom tworzenia dyskursu, zwanym czasem ogólnie European governance.

Jednocześnie w wyniku zaistnienia pewnych okoliczności sytuacja w obu wioskach różni się zasadniczo. W jednej z osad zinstytucjonalizowane działania integracyjne przybrały szczególnie intensywny charakter i bardzo wyraźnie przyczyniły się do ukształtowania charakterystycznych relacji między Romami i nie-Romami. Najbardziej wyrazistym symbolem wsparcia, jakie Romowie $\mathrm{z}$ osady otrzymali $\mathrm{w}$ darze, jest nowy wielorodzinny budynek, stopniowo oddawany do użytku w latach 2007-2014 (i właściwie wciąż adaptowany do rosnących potrzeb). W drugiej osadzie znaczna część Romów stała się członkami Kościoła Zielonoświątkowego, co w ich przypadku radykalnie wpłynęło na dotychczasowy sposób życia, a w szczególności na utrzymywanie się społecznych granic emocjonalnego zaangażowania. 


\section{Bartnica Dolna ${ }^{3}$}

W trakcie moich kolejnych wizyt w osadzie w latach 2011-2017 we wsi mieszkała około 70-80-osobowa grupa Romów Bergitka. Do 2014 roku, aby dostać się do osady, trzeba było przejść przez drewniany most, będący w bardzo złym stanie. Obecnie w ramach kontynuacji inwestycji infrastrukturalnych na rzecz społeczności romskiej wybudowano także nowy betonowy most. Zarówno dom, jak i most są bardzo czytelnymi znakami czasów programu integracji Romów. Projekt budowy domu (obu części) dla Romów został opracowany w listopadzie 2004 roku i przewidywał postawienie budynku mieszkalnego o łącznej powierzchni użytkowej $575 \mathrm{~m}^{2}$, na których miało powstać 12 mieszkań. Budynek stanął na terenach przylegających od południa do rzeki Bartnica, a od północy do dość stromego zbocza. Inwestorem została gmina Bartnica Górna, która wystarała się o działkę pod budowę.

W raporcie przedstawiciela Rzecznika Praw Obywatelskich, który był we wsi w październiku 2014 roku, warunki mieszkaniowe Romów oceniono jako „bardzo dobre” (Driatania Rzecznika Praw Obywatelskich... 2014, 24). Cała inwestycja została zrealizowana dzięki dofinansowaniu ze środków budżetu państwa w ramach rządowego programu integracji Romów przekazanych przez ówczesne Ministerstwo Spraw Wewnętrznych i Administracji.

Poza zasiłkami z pomocy społecznej i darami (którymi Romowie okazyjnie handlują wśród nie-Romów) otrzymywanymi od organizacji pomagajacych Romom głównymi sposobami zdobywania środków na utrzymanie jest zbieractwo złomu oraz odzyskiwanie miedzi i innych metali ze starych przewodów i opon. Sporadycznie Romowie bywali zatrudniani przez gminę przy okazji okolicznościowych imprez jako osoby odpowiedzialne za transport i rozkładanie infrastruktury. Odzyskiwanie metali, choć stosunkowo opłacalne, jest źródłem licznych napięć z mieszkańcami Bartnicy Dolnej ze względu na roznoszący się gryzący dym i smród z wypalanych przewodów. Osoby mieszkajace w bezpośrednim sąsiedztwie w bardzo emocjonalny sposób przekonywały mnie o wielkiej uciążliwości zwyczaju wypalania przewodów. Wielu twierdzi, że ponieważ Romowie wszędzie mają teraz, w czasach programów integracji, „układy, układziki”, nikt nie chce pomóc, a nawet uwierzyć, ich sąsiadom nie-Romom.

\footnotetext{
${ }^{3}$ Wszystkie nazwy własne w artykule zostały zmienione, by zmniejszyć prawdopodobieństwo identyfikacji osób badanych.
} 
Mieszkańcy Bartnicy Dolnej zwracają uwage, że w ostatnich latach pojawiło się wiele tzw. „projektów” dla Romów, które sprawiaja, że otrzymują oni pomoc z różnych źródeł. W ich opinii wsparcie dla Romów nie jest wystarczająco koordynowane: niektórych rzeczy otrzymują zbyt dużo (np. kilka kompletów podręczników szkolnych, które są następnie sprzedawane miejscowym za bardzo niskie kwoty). Wśród mieszkańców wsi wywołuje to oburzenie, poczucie frustracji i przekonanie, że pomoc dla Romów jest nadużyciem. Napięcie pogłębia się w sytuacji, gdy Romowie dość zdecydowanie domagają się należącej się im (w ich opinii) pomocy materialnej:

Taka postawa roszczeniowa już trwa od momentu, kiedy już się zaczęła ta budowa, kiedy te programy unijne... Maja przesyt tego wszystkiego, tak ja to określam, tak tutaj nawet określaja, jest przesyt. (...) Ludzie maja naprawdę pewnego rodzaju dyskomfort, ponieważ no wszędzie te romskie, romskie, romskie. A codziennie widzą pijanych ojców śpiewajacych, nic nierobiących w koszulkach eleganckich, bo oni są ładnie ubrani (wywiad 7, 2012).

Przywołuje się argumenty ukazujące „psucie” Romów przez oferowane im formy pomocy:

[Kiedyś Romowie] pletli kosze, zrobili motykę, robili grabki. Szedł po wsi i: kupcie panie grabki, no to ja... zawsze ktoś kupił. On coś robił, a teraz, naprawdę, nie robią kompletnie nic. Nic! (...) Ja to słyszę, że oni byli tacy normalniejsi. Oni byli tacy... no nie było czegoś takiego, że mnie się należy (wywiad 8, 2012).

Szczególny rodzaj frustracji wśród nie-Romów budzi brak zrozumienia ze strony zewnętrznych autorytetów dla odczuwanej przez nich uciążliwości sąsiedztwa z Romami. Podkreślają, że Romowie otrzymują niezasłużone wsparcie ze strony swoich stowarzyszeń, „rzecznika”, organizatorów projektów oraz mediów, wobec których nawet gminny samorząd pozostaje bezradny. Są przekonani, że Romowie bardzo zręcznie nadużywają otrzymywanego wsparcia, co wzbudza niechęć i tradycyjnym uprzedzeniom nadaje nową jakość, jak podsumowała to jedna z mieszkanek z bezpośredniego sąsiedztwa: „Kiedyś byli Cyganie, a teraz są cwaniacy” (wywiad 45, 2014).

Praktyki integracyjne wpływają także na relacje społeczne w szkole. Zgodnie $z$ założeniami polityki integracji obok aktywizacji zawodowej dorosłych edukacja dzieci romskich jest jedna z podstawowych taktyk integrowania 
Romów. Około 20 dzieci z osady chodzi do szkoły podstawowej w pobliskim Lutnem, a kilkoro do gimnazjum w Bartnicy Dolnej. Miejscowi nauczyciele twierdza, że uczniowie romscy są dobrze ubrani i maja przybory szkolne. W wywiadach podkreślają także, że dzieci romskie doskonale znaja swoje prawa (wynikające ze statusu mniejszości czy np. z orzeczonej niepełnosprawności) i opinię na ten temat potrafia dobitnie wyartykułować, gdy zachodzi taka potrzeba.

Dla mieszkańców Bartnicy podstawową zasadą przydzielania zasobów oraz statusów społecznych w ramach praktyk integrowania Romów powinna być chęć (rzeczywista gotowość) do pracy fizycznej i poświęcanie się dla utrzymania rodziny. W wielu sytuacjach deklaruja, że chcą Romom dawać więcej, np. ofiarować pole do obrobienia lub zaoferować pracę przy własnym gospodarstwie, byle tylko Romowie byli skłonni uznać ich własny system dystrybucji statusu społecznego. Obserwowane przez nich sposoby pomagania Romom, jak np. szkolenia czy przekazywanie (następnie odsprzedawanych) darów od organizacji pozarządowych sa w ich oczach nie tylko bezsensowne, ale przede wszystkim niemoralne.

Romowie integrację rozumieją jako samo zaangażowanie w praktyki integracyjne, np. uczestnictwo w projektach, posyłanie dzieci do szkoły i przedszkola oraz zaangażowanie w działalność instytucji nie-Romów, np. umiejętne wnioskowanie o pomoc. Upodabniają swoje życie do życia nie-Romów, ale w taki sposób, by nie zrezygnować z najistotniejszych elementów swej koncepcji świata. Samo otrzymanie domu i mieszkanie w nim jest dla nich formą zaangażowania w integrację, dlatego powinno zostać odpowiednio nagrodzone w postaci wyższego statusu. W ich oczach pomysł na nowy system społeczny oraz związana z nim pomoc nie pochodzą od konkretnych mieszkańców Bartnicy, ale od abstrakcyjnej Unii Europejskiej. Zatem wdzięczność i relacja wzajemności wobec kogoś konkretnego nie ma większego sensu.

Górale tworzą własne narracje romskich nadużyć i ogólnej szkodliwości pomagania Romom. W ten sposób działania integracyjne doprowadziły do sytuacji, w której wiele tradycyjnych uprzedzeń zostało uwypuklonych i zintensyfikowanych (do czego przyczyniły się liczne doświadczenia projektów integracyjnych i ich domniemany wpływ na mieszkańców romskiej osady). Wielu mieszkańców Bartnicy niezależnie od deklarowanego przekonania, że „projekty są szkodliwe”, uważa, iż Romom trzeba pomagać, a nawet, że pomoc powinna być zwiększona. Doświadczenie zmian relacji władzy między obiema społecznościami, wynik integracyjnej praktyki odgórnego „empowermentu” (dyskryminacji pozytywnej) dokonuje się dzięki zewnętrznym 
relacjom Romów z organizacjami etnicznymi, instytucjami wspierającymi, mediami. Narracje o integracyjnych nadużyciach gromadzone są na użytek kontaktu z osobami z zewnątrz, takimi jak np. przyjeżdżający do wsi antropolodzy. To, co wydaje się doskwierać mieszkańcom Bartnicy, to dyskredytowanie przez osoby z zewnątrz ,autentyczności” podstaw odczuwanej wobec Romów obcości i dystansu społecznego. W wiosce można obserwować dwie strategie:

1. Potlaczu: deklarowania przekonania, że Romom należy dawać więcej, zgodnie z zasada, że wtedy prawda o nich wyjdzie sama. Zdarzające się w trakcie praktyk integracyjnych nadużycia ze strony Romów są traktowane jako empiryczne dowody odrzucenia dobrej woli dajacych. Zakładane nieodwzajemnienie darów integracyjnych służy deprecjacji pozycji, jaką daje Romom polityka „empowermentu”. Pozwala wrócić do tradycyjnej dysproporcji relacji między obiema społecznościami. Podstawowym działaniem służącym temu celowi jest kolekcjonowanie i przekazywanie osobom spoza społeczności wsi narracji o złym wpływie praktyk integracyjnych.

2. Otwartej wrogości: oburzenia sytuacją, w której „Romom wszystko wolno". Ten rodzaj postawy ujawniany jest w sytuacjach większej zażyłości przez bliskich sąsiadów romskiej osady. Opisywane są zajścia na pograniczu bijatyki między Góralami a Romami z osady, zazwyczaj wspieranymi przez Romów z sąsiednich osad. Podkreślana jest wywołująca frustrację bezradność policji, która w opinii nie-Romów z Bartnicy albo boi się interweniować „sprawiedliwie”, by nie być oskarżaną o rasizm, albo nie ma wystarczającej siły i autorytetu.

\section{Czaplaki}

Zdecydowana większość mieszkańców romskiej osady przy wsi Czaplaki utrzymuje się z opieki społecznej. Zarówno mieszkańcy wsi, jak i Romowie postrzegaja siebie jako odrębne społeczności, mimo że Romowie sprowadzili się tu bardzo dawno i mieszkańcy uważają, że byli tu „od zawsze”. Co do momentu ich przybycia do wsi występują pewne rozbieżności, jednak z całą pewnością byli już we wsi w 1934 roku (Źółtek 2008, 230-231). Wówczas, w czasie wielkiej powodzi, niewielkiej społeczności Cyganów udzielono pomocy materialnej i zezwolono na osiedlenie się na obecnie 
zajmowanym terenie. W raporcie Rzecznika Praw Obywatelskich (Driałania Rzecznika Praw Obywatelskich... 2014) warunki mieszkaniowe w tej osadzie określane sa jako najlepsze spośród osiedli romskich w tym regionie. Sytuację poprawiły budowane w ramach rządowego programu wsparcia dla Romów i zaangażowania środków własnych gminy kontenery mieszkalne (ze względu na nieuregulowaną sytuację własności gruntu nie można było postawić zwykłych budynków). Jest to siedem postawionych na prowizorycznym, betonowym fundamencie niewielkich domków, z których największe mają około $60 \mathrm{~m}^{2}$. Sami Romowie z Czaplak twierdzą, że przed ich nawróceniem była to „najbardziej niebezpieczna” i „najgorsza” z romskich osad.

W trakcie prowadzenia badań w latach 2013-2016 kilkudziesięcioosobowa grupa miejscowych Romów angażowała się w uczestnictwo we wspólnocie zielonoświątkowców. Podczas badań etnograficznych, poza pogłębionymi wywiadami, miałem możliwość wielokrotnie uczestniczyć w odbywających się w osadzie spotkaniach modlitewnych, a także w nabożeństwach zboru w Nowym Targu, w których obok nie-Romów aktywny udział brali także Romowie z Czaplak. Nie należąc do Kościoła Zielonoświątkowego, przyglądając się odbywającym się w mojej obecności modlitwom niejako z zewnattrz, z pewnym dystansem, zawsze w takich sytuacjach odczuwałem silne emocje. Kobiety etnografki, z którymi prowadziłem badania, w każdej takiej sytuacji płakały. Modlitwy w osadzie odbywają się zazwyczaj trzy razy w tygodniu. Biora w nich udział wszyscy wierzący. Wśród około 80-100 mieszkańców osady (liczbę tę trudno ustalić ze względu na liczne migracje krajowe i zagraniczne) nawróceni stanowią większość. We wspólnocie wiernych są takie osoby, które nawróciły się od początku ewangelizacji w osadzie i już od wielu lat trwaja przy nowych zasadach, oraz osoby przeżywające wahania i okresowe kryzysy. Pierwsze nawrócenia miały miejsce w 2001 roku (zob. Witkowski 2016).

Konwersja religijna, jakiej intensywnie doświadczają, wywołała u nich emocjonalne, ale i intelektualne dążenie do przekroczenia tradycyjnie odczuwanego przez nich dystansu w stosunku do nie-Romów - jak sami przyznają - jednego z najważniejszych wyznaczników ich dotychczasowego życia. Jednocześnie deklaruja, że starają się nie odrzucać romskiej tożsamości, a raczej wypracować jej nową formę zgodną z zasadami swojej wiary.

Romscy mieszkańcy Czaplak w kontaktach z badaczami właściwie cały czas dążą do nawrócenia nieoczekiwanych przybyszy. Ich wypowiedzi są przepełnione charakterystycznymi sformułowaniami o konotacji religijnej. Używają określeń pozwalających rozumieć spotkanie z etnografami jako 
„wolę Boga” lub „boską ingerencję” w ich i nasze życie. Przy tym chętnie i niezwykle gościnnie przyjmują nas w swoich domach. Żaden z nich nigdy nie poprosił nas o jakiekolwiek wsparcie materialne, co - muszę przyznać w świetle doświadczeń z Romami z Bartnicy wywoływało zaskoczenie, ale nade wszystko konfuzję i poczucie nadużywania gościnności. Ich relacje o przemianie, jaka dokonała się pod wpływem „Bożej łaski”, można, choć z pewnymi zastrzė̇eniami, w niektórych obszarach potraktować jako klucz do zrozumienia równoległej sytuacji w Bartnicy Dolnej. O ile w trakcie badań w Bartnicy miałem możliwość doświadczyć kontaktu z Romami z perspektywy gadzia-badacza, o tyle mieszkańcy osady w Czaplakach dostarczają werbalnych interpretacji pewnych okoliczności, które w Bartnicy są etnograficznym odczuciem ,z wewnątrz”. Po nawróceniu sposób opisu i jednocześnie wyraźnej oceny starych romskich obyczajów pochodzi z innej, zewnętrznej wobec tej tradycji perspektywy aksjonormatywnej.

Romowie opisują swój sposób myślenia i zachowania po nawróceniu jako zupełnie nowy. Zawsze pojawia się on w opozycji do starych zwyczajów, ocenianych dziś jako coś niewyobrażalnego i niestosownego: „My już nie mamy myśli, żeby coś ukraść, coś zrobić źle. Jak by to było przed Bogiem?!”. Każda relacja przedstawiana jest bardzo emocjonalnie: moment nawrócenia, utrzymywany zazwyczaj w tonie chrześcijańskiego świadectwa, odczuwa się nie tylko jako zyskanie nowego intelektualnego sposobu patrzenia na świat, ale także jako połączone z silnym afektem doświadczenie cielesne, np. wielu mężczyzn stan ten określa jako „zwalenie z nóg”. Najważniejszy z obszarów, w jakim zaszły zmiany, to relacje z nie-Romami. Zgodnie z zasadami wiary „Bóg nie robi różnicy, czy to Cygan, czy nie” (wywiad 51, 2015), „W niebie nie będzie osobno tu Rom, tu gadzio” (wywiad 52, 2015). Jedna $z$ najbardziej zaangażowanych religijnie kobiet opowiadała historię, gdy w trakcie wizyty w przychodni lekarskiej znalazła należący do jakiegoś, co podkreśla, gadzia portfel. Domyśliwszy się, kto może być jego właścicielem, zwróciła znaleziony przedmiot. Cała narracja ma wydźwięk niesamowitego wydarzenia, niemal cudu uczynionego za sprawą Boga, możliwego tylko w sytuacji jej duchowej przemiany. W jej rozumieniu sytuacja, w której Rom oddaje gadziowi znaleziony portfel z pieniędzmi przed nawróceniem, byłaby niedorzeczna: „A dawniej jakby się tak znalazło... (śmiech)... do kieszeni i już... I jak się okazało, to było ponad 4 tysiące. Ja mówię: Panie...! Wyszłam taka radosna, szczęśliwa! Dziękuję ci, Jezu, że ja dałam, że oddałam... Ile bym się pocieszyła? Chwilę i co? Potem bym Ducha Świętego zasmuciła...” (wywiad 49, 2015). 
Jeden z mężczyzn, o którym wiemy, że jeszcze pół roku wcześniej nadużywał alkoholu, a okresy religijnego zaangażowania przeplatał „momentami odejścia od Boga", z wielkim zapałem opowiada o równości małżeńskiej jako zjawisku nowym i trudnym do uwierzenia, niemal cudownym: „Ja normalnie: zamiatam, myję talerze. Już nie pamiętam, kiedy żonę uderzyłem taki jestem teraz". Odnosząc się do naszej wizyty stwierdza, iż jest przekonany, że gdybyśmy przyszli przed nawróceniem się Romów, sytuacja wygladałaby zupełnie inaczej - że po wejściu do osady zostalibyśmy przede wszystkim określeni jako gadzie w znaczeniu pejoratywnym. W tym miejscu symuluje prawdopodobne rozmowy romskich mężczyzn wypowiadane z agresywną ekspresja: „Co? Gadzio??? Co to za gadzio?!”. Następnie mężczyzna zostałby najpierw upity, a potem „ogołocony” i pobity.

Należący do Kościoła Zielonoświątkowego Romowie w porozumieniu z nieromskim pastorem ze zboru w Nowym Targu podjęli działalność misyjna $\mathrm{w}$ innych społecznościach romskich. Jednym $\mathrm{z}$ istotnych miejsc prowadzenia działalności ewangelizacyjnej jest Górny Śląsk. Napotkali jednak zasadniczą i na tę chwilę niemożliwą do przezwyciężenia trudność: tamtejsi Romowie nie chcą tworzyć wspólnoty religijnej razem z gadziami. Zasady wiary ewentualnie są w stanie przyjąć, ale wspólne modlitwy i nabożeństwa z „Polakami” są dla nich nie do pomyślenia. Romowie z Czaplak są tym zbulwersowani, ponieważ „W niebie nie będzie osobno tu Rom, tu gadzio. (...) Przed Bogiem staniemy równo". Innym miejscem prowadzenia ewangelizacji jest położona niedaleko Bartnica Dolna. Jednak tamtejsi mieszkańcy romskiej osady nie chcą wstapić do Kościoła Zielonoświątkowego ze względów pragmatycznych: nie chca pogarszać stosunków, jakie utrzymują z katolicką większościa. Jedna z Romek z Czaplak tłumaczy ich: „Nie chcą się nawrócić, bo wieś by ich wyklęła". W tamtejszej osadzie podobne wyjaśnienie przekazywano także nam: „Boże [dramatycznie łapie się za głowę], a jak byśmy tu potem żyli?!”.

Zmianie ulegaja także relacje $z$ władzami oraz powszechne obecnie sposoby załatwiania przez Romów swoich problemów - to, co w Bartnicy określane jest „roszczeniowością” Romów:

teraz nam Bóg będzie pomagać, to się napisze pisma również o jakąś pomoc, o dotację, o zakup kręgów, czy w ogóle. Wie pani co, naprawdę mógłbym zrobić taką małą aferę, na takim większym polu, naprawdę. Mam takich znajomych, że by się zdziwili, jakich ja mam znajomych i w ogóle ludzi, którzy by aferę zrobili. Im się nogi trzęsa, ale nie chcę jako 
chrześcijanin walczyć w taki sposób. Ja chcę z tym wszystkim zwracać się do Boga. Może Bóg nie chce itd., żeby pchać się w takie sprawy? Wie pani co, to tak samo, jak tutaj z mieszkaniami czy w ogóle... co żeśmy zrobili? Bóg o nas zadbał. Mamy to, co mamy, dziękujemy Bogu, nie? Na ile nas będzie stać... nie chcemy też być bezczynni, ale nie chcemy, żeby się kłócić, walczyć ze sobą itd... oskarżać... nie... (wywiad 52, 2015).

Zmiany te są dostrzegane także przez nieromskie otoczenie, co w opowieściach Romów jest z dumą podkreślane i wydaje się dostarczać im satysfakcji:

Właśnie mnie chwalili ludzie i Bożenkę: Co się z wami stało? Wy się wyróżniacie. Jak w tym busie powiedział... taki Rom tutaj z busami jeździ do Zakopanego, powiedział tak podobno, że ja tam nie pasuję... (śmiech wszyscy)... że ja nie pasuję... I to parę ludzi tak powiedziało, że ja tam nie pasuję, że nie powinnam tam siedzieć (śmiech). A gdzie mam siedzieć? (wywiad 52, 2015).

Nie-Romowie z Czaplak, z którymi rozmawiałem o dostrzeganych zmianach wewnątrz społeczności romskiego osiedla, uważaja, że choć w pewnych obszarach zmiany „na lepsze” sa oczywiste, to pewne tradycyjne przyzwyczajenia nie ulegaja zmianie, a pewne stare złe przyzwyczajenia zostaja i funkcjonują w ukryciu.

Zauważane i doceniane są zmiany dotyczące nadużywania alkoholu i wszczynania awantur: w opinii nieromskiego otoczenia nawróceni Romowie całkowicie lub przynajmniej przez długi czas nie pija. Jeśli chodzi o umiejętność pracy, wciąż panuje przekonanie, że Romowie „nie potrafią” tego robić i uczestnictwo w kościele zielonoświątkowym niewiele tu zmienia. Choć sami Romowie sa przekonani, że ich zaangażowanie religijne diametralnie zmieniło stosunek miejscowych Górali, na podstawie wywiadów, jakie przeprowadziłem, wydaje się, że zmiany te zachodzą bardzo powoli; miejscowi nie-Romowie określaja je jako fragmentaryczne, co mocno kontrastuje z „całkowita zmianą”, „nowym życiem”, o którym mówią Romowie. Niektórzy z obserwatorów sytuacji w osadzie wciąż pozostają sceptyczni co do autentyczności religijnego zaangażowania i trwałości dobrych sposobów zachowania. Swoje sądy opieraja na długoletnim doświadczeniu kontaktów z Romami i przekonaniu, że z uczestnictwa we wspólnocie wiernych czerpią oni korzyści materialne. 


\section{Konkluzja}

Jedną z ciekawszych myśli przedstawionych w résumé ostatnich czterech dziesięcioleci antropologicznych badań nad Romami autorstwa Michaela Stewarta (Stewart 2013) jest postulat zwrócenia baczniejszej uwagi na szczególnie emocjonalny charakter romskich tożsamości. W swojej syntezie Stewart zauważa, że zasadnicze zmiany romskiego sposobu życia dokonywały się tylko w związku z - nazwijmy to - emocjonalnymi ofertami, jakie otrzymywali ze świata zewnętrznego. Chodzi tu przede wszystkim o zaangażowanie charyzmatycznych ruchów religijnych, głównie kościołów ewangelikalnych, których popularność w skali europejskiej w środowiskach romskich, mimo pewnych wahań, wydaje się systematycznie rosnąć. Nie sądzę, by sprowadzanie konwersji religijnych wyłącznie do ich emocjonalnego wymiaru było właściwym rozwiązaniem. Jednak faktem jest, że w świetle większości badań, gdy idzie o Romów, realne i długotrwałe nawrócenia pojawiają się przede wszystkim w przypadku pewnego typu kościołów charyzmatycznych. W każdym z nich rutynowe uczestnictwo wydaje się związane z niezwykle silnym pobudzeniem emocjonalnym. Jednocześnie dominacja wymiaru afektywnego nie oznacza braku istotnego zaangażowania intelektualnego w konstrukcję nowego obrazu świata, czego moglibyśmy oczekiwać po społeczności, w której analfabetyzm nie jest szczególną rzadkościa, a płynne czytanie jest raczej wyjątkiem. Innymi słowy, trudno jest obronić tezę, że religijna emocjonalność jest dla Romów jedynie prostszą formą dochodzenia do zaangażowania religijnego, a następnie jego podtrzymywania.

Według Stewarta zdecydowana przewaga emocjonalnego wymiaru społecznej tożsamości nad jej komponentem poznawczym może być głównym uwarunkowaniem wszelkich romskich identyfikacji. W pewnych okolicznościach zjawisko to umożliwia uporczywe trwanie, w innych - radykalną zmianę ich sposobu życia. Na podstawie przedstawionych rozważań można postawić hipotezę, że oddziaływanie na sferę afektywną jest podstawowym warunkiem skuteczności adresowanej do nich polityki. Fiaskiem okazywały się stosowane w różnych kontekstach społecznych i historycznych strategie działania wobec Romów, w tym - jak wszystko wskazuje - współczesna europejska polityka inkluzji. Wbrew oczekiwaniom kolejnych autorów polityki stosowanej wobec Romów, granica etniczna, odpowiedzialna za nieakceptowany z punktu widzenia nieromskich zbiorowości „romski sposób życia”, wciąż pozostaje aktualna, generując nowe odsłony międzygrupowych napięć. 


\section{Literatura}

Barany Z., 2002, The East European Gypsies. Regime Change, Marginality, and Ethnopolitics, Cambridge.

Janusz G., 2011, Ochrona praw mniejszości narodowych w Europie, Lublin.

Klimova-Alexander I., 2005, The Romani Voice in World Politics, Aldershot.

Liegeois J.-P., 2007, Roma in Europe, Strasburg.

Nowicka E., 2003, Romowie o sobie i dla siebie. Nowe wyzwania i perspektywy, w: Nowicka E., red., Romowie o sobie $i$ dla siebie. Nowe problemy $i$ nowe dziatania w pieciu krajach Europy Środkowo-Wschodniej, Warszawa.

Połeć W., 2003, Romowie na Stowacji. Marginalizacja i postęp, w: Nowicka E., red., Romowie o sobie $i$ dla siebie. Nowe problemy i nowe driałania w pięciu krajach Europy Środkowo-W schodniej, Warszawa.

Program integracji spoteçności romskiej w Polsce na lata 2014-2020, Ministerstwo Administracji i Cyfryzacji, 2014.

Driałania Rzuçnika Praw Obywatelskich na ræecz mniejszości romskiej w wojewódz̨twie małopolskim. Raport z. wizytacji osiedli romskich, Biuro Rzecznika Praw Obywatelskich, 2014.

Sobotka E., 2010, Special Contact Mechanisms for Roma, in: Weller M., Nobbs K., eds., Political Participation of Minorities, Oxford.

Stewart M., 2013, Roma and Gypsy "Ethnicity" as a Subject of Anthropological Inquiry, "Annual Review of Anthropology", no. 42.

Szewczyk M., 2013, Społeczność romska - instytucjonalne wy røanie dla paradygmatu spójności Unii Europejskiej, „Nierówności Społeczne a Wzrost Gospodarczy”, nr 26.

Talewicz-Kwiatkowska J., 2013, Wplyw aktywności finansowej Unii Europejskiej na położenie spoteczne Romów w Polsce, Kraków.

Vermeersch P., 2006, The Romani Movement: Minority Politics and Ethnic Mobilization in Contemporary Central Europe, New York.

Witkowski M., 2003, Romowie w Czechach. Podriaty i wspótdriałanie, w: Nowicka E., red., Romowie o sobie $i$ dla siebie. Nowe problemy $i$ nowe driatania w pieciu krajach Europy Środkowo-W schodniej, Warszawa.

Witkowski M., 2016, Polityka i antropologia. Praktyki integrowania Bergitka Roma w karpackich wioskach $w$ Polsce, Kraków.

Wódz K., Witkowski M., 2013, Civil Society and Anti-Discrimination Policy in a Homogenous Country: The case of Poland, in: Fella S., Ruzza C., eds., Anti-Racist Movements in the EU. Between Europeanization and National Trajectories, London.

Wódz K., Wódz J., 2007, Europa urzędnikón brukselskich çy Europa obywateli? U źródet deficytu demokratycznego w Unii Europejskiej, w: Wódz K., red., Negocjowana demokracja, cayli europejskie governance po polsku, Warszawa.

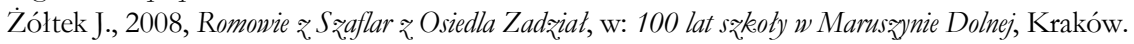

